\title{
The pituitary-thyroid axis in healthy men living under subarctic climatological conditions
}

\author{
J Hassi, K Sikkilä ${ }^{1}$, A Ruokonen ${ }^{2}$ and J Leppäluoto ${ }^{1}$ \\ Oulu Regional Institute of Occupational Health, Oulu, Finland \\ ${ }^{1}$ Department of Physiology and Institute of Arctic Medicine, University of Oulu, Oulu, Finland \\ ${ }^{2}$ Department of Clinical Chemistry, Oulu University Hospital, Oulu, Finland \\ (Requests for offprints should be addressed to J Leppäluoto, Department of Physiology, University of Oulu, POB 5000, 90014 Oulun yliopisto, Finland; \\ Email: juhani.leppaluoto@oulu.fi)
}

\begin{abstract}
In order to evaluate the effects of climatic factors on the secretion of thyroid hormones and TSH in a high latitude population, we have taken serum and urine samples from 20 healthy men from northern Finland $\left(67^{\circ}-68^{\circ} \mathrm{N}\right)$ every 2 months for a period of 14 months. Serum free triiodothyronine $\left(\mathrm{T}_{3}\right)$ levels were lower in February than in August $(3.9$ vs $4.4 \mathrm{pmol} / 1, P<0.05)$ and TSH levels were higher in December than during other months $(2 \cdot 1$ vs $1.5-1.7 \mathrm{mU} / 1, P<0 \cdot 01)$. Serum total and free thyroxine $\left(T_{4}\right)$, total $T_{3}$ and reverse $T_{3}$ levels and urinary $T_{4}$ levels were unchanged. Urinary $T_{3}$ levels were significantly higher in winter than in summer. Serum free $\mathrm{T}_{3}$ correlated highly significantly with the outdoor temperature integrated backwards weekly for $7-56$ days $(r=0 \cdot 26$ for $1-56$ days) from the day when the blood samples were taken. Serum TSH did not show any significant correlation with the thyroid hormones or with the integrated temperature
\end{abstract}

of the previous days, but it did show an inverse and significant correlation $(r=-0 \cdot 31)$ with the ambient luminosity integrated backwards for 7 days from the day when the blood sample was taken. The gradually increasing correlation between outdoor temperatures and serum free $T_{3}$ suggests that the disposal of thyroid hormones is accelerated in winter, leading to low serum free $T_{3}$ levels and a high urinary free $T_{3}$ excretion. Since there was no correlation between thyroid hormones and serum TSH, the feedback mechanism between TSH and thyroid hormones may not be the only contributing factor, and other factors such as ambient luminosity may at least partly determine serum TSH in these conditions. Also urinary free $T_{3}$ appears to be a novel and non-invasive indicator for thyroid physiology.

Journal of Endocrinology (2001) 169, 195-203

\section{Introduction}

Thyroid hormones are the main regulators of nonshivering thermogenesis and in some species their secretion has been shown to be activated in a cold environment. There are several previous reports which describe the seasonal variation of the pituitary-thyroid axis in humans. Japanese subjects living in unheated dwellings had higher serum total triiodothyronine $\left(\mathrm{T}_{3}\right)$ levels in winter than in summer, but subjects working outdoors showed no differences in serum $T_{3}$ or thyroxine $\left(T_{4}\right)$ between summer and winter (Nagata et al. 1976). High serum total $T_{3}$ and $T_{4}$ levels in winter were also found in laboratory workers in the Netherlands (Smals et al. 1977) and the UK (Harrop et al. 1985). This would indicate that the pituitary-thyroid axis becomes directly activated during the cold season. Other studies have, however, led to opposite results. In healthy subjects serum total $\mathrm{T}_{4}$ levels were similar during all seasons, but the serum thyrotrophin (TSH) response to TSH-releasing hormone (TRH) was greater in winter than in summer (Konno 1978, Harrop et al. 1985). In hypothyroid subjects, lower serum $\mathrm{T}_{4}$ levels and higher serum TSH levels and TSH responses to TRH were found in winter rather than in summer (Konno \& Morikawa 1982). In another study, involving large populations, the serum TSH levels of young, middle-aged and old Italian subjects were at their highest in December in the middleand old-age classes (Simoni et al. 1990), but no seasonal changes were seen in younger subjects (Pasquali et al. 1984, Simoni et al. 1990). In a recent study both serum TSH and free $\mathrm{T}_{3}$ were highest in winter in healthy Belgian subjects (Maes et al. 1997). Elevated TSH levels in winter may relate to decreased iodothyronine deiodination in the pituitary gland or to decreased release of somatostatin or dopamine from the hypothalamus, but the increased TSH response to TRH in winter rather suggests that there is a lack of active thyroid hormones during the cold season. Studies with subjects wintering in the Antarctic bases support this finding, for decreased serum total $T_{3}$ and $T_{4}$ and increased TSH levels were found 
after an Antarctic winter (Vining et al. 1983). It was also demonstrated that after Antarctic cold exposure (42 weeks) serum total and free $T_{4}$ did not change, but serum total and free $\mathrm{T}_{3}$ decreased and the serum TSH response to TRH increased (Reed et al. 1986, 1988). When increased testing frequency and improved assays were used, small decreases in serum total and free $T_{4}$ and an increase in serum TSH during Antarctic residence were observed (Harford et al. 1993). The decrease in the serum thyroid hormone levels was likely due to an increased disposal of thyroid hormones during the cold exposure (Reed et al. 1990b).

Thus, there appears to be a discrepancy with regard to the cold-induced long-term changes in the serum levels of thyroid hormones and TSH and to the mechanisms causing these effects. Part of this discrepancy is evidently due to the fact that most studies were performed in geographical areas in which the seasonal temperature seldom goes below freezing point. Studies carried out in the Antarctic show that long-term cold exposure may initiate a cascade of events that lead to small decreases in the circulating levels of thyroid hormones, resulting in a reflex elevation of serum TSH (Harford et al. 1993). On the contrary, the results of a study performed on Belgian subjects suggest that the annual variation in TSH partly determines the variation in serum $\mathrm{T}_{3}$ (Maes et al. 1997). Therefore we wanted to address the following questions in the present study. Are there annual changes in the levels of thyroid hormones and TSH and are there temporal correlations between these hormones and ambient temperature or luminosity in healthy males living in a circumpolar area? The subjects we chose for the study come from northern Finland, which is continuously exposed to great seasonal changes in environmental temperature and luminosity. Our results show that in winter, serum free $\mathrm{T}_{3}$ levels are low and serum TSH levels high, the former related to low ambient temperature and the latter to low luminosity. Our findings indicate that bodily disposal of thyroid hormones increases during the cold season.

\section{Materials and Methods}

Twenty healthy Caucasian males aged 26-40 years from the counties of Sodankylä and Äkäslompolo, Kolari (67$68^{\circ} \mathrm{N}, 24-26^{\circ} \mathrm{E}$ ) gave their informed consent for this study, which was accepted by the Ethics Committee of the Medical Faculty, University of Oulu. They were outdoor workers and their daily outdoor stays were recorded. The subjects visited a nurse's office every 2 months at 0900 $1100 \mathrm{~h}$. On these occasions blood and urine samples were taken and body weight was measured. A $24 \mathrm{~h}$ recall diet interview (Laitinen et al. 1996) was also taken by the nurses. Blood samples were centrifuged and stored at $-20{ }^{\circ} \mathrm{C}$. First-voided urine in the morning of the day of the visit was measured in a graduated cylinder, acidified with $0 \cdot 1 \mathrm{M} \mathrm{HCl}$ and stored in $10 \mathrm{ml}$ portions at $-20{ }^{\circ} \mathrm{C}$. Blood and urine samples were taken in April (no urine samples), June, August, October, December, February and again in April. Daily sums of solar radiation and daily mean temperature (four recordings for each) measured by the Sodankylä observatory $\left(67^{\circ} 20^{\prime} \mathrm{N}\right)$ were obtained from the Department of Aerial Sciences (Helsinki, Finland).

Serum free $\mathrm{T}_{3}\left(\mathrm{Mx} \mathrm{T}_{3}\right.$; Abbott Diagnostics, Abbott Park, IL, USA), total $\mathrm{T}_{3}$, free $\mathrm{T}_{4}$ and total $\mathrm{T}_{4}$ (Farmos Diagnostica, Turku, Finland) were measured by commercial RIA kits and TSH by a kit from Diagnostic Products, Los Angeles, CA, USA according to the manufacturers' instructions. The normal values for serum free $T_{3}$ were $3 \cdot 5-7 \cdot 5 \mathrm{pmol} / 1$, for $\mathrm{T}_{3} 1 \cdot 1-2 \cdot 5 \mathrm{nmol} / 1$, for free $\mathrm{T}_{4} 8-$ $25 \mathrm{pmol} / 1$, for $\mathrm{T}_{4} 55-140 \mathrm{nmol} / 1$ and for TSH $0 \cdot 2-4 \mathrm{mU} /$ 1. The antiserum for reverse $T_{3}\left(r T_{3}\right)$ was purchased from UCB Bioproducts (Brussels, Belgium), code i592, and ${ }^{125} \mathrm{I}_{\mathrm{rT}} \mathrm{T}_{3}$ from Amersham International, Amersham, Bucks, UK, code IM 105. The sensitivity of the $\mathrm{rT}_{3}$ assay was $0.06 \mathrm{nmol} / \mathrm{l}$. The intra- and interassay coefficients of variation in these assays were $1-6 \%$ and $9-16 \%$ respectively. Serum albumin was measured using a Cobas Intergra Offmatic analyser (Hoffman-La Roche, Basel, Switzerland).

Urine free $T_{3}$ and $T_{4}$ were measured by kits from Farmos Diagnostica after purification by Sep-Pak cartridges (Waters, Milford, MA, USA) as follows. Two millilitres of urine were acidified by acetic acid to $\mathrm{pH}$ 3.5-4.0 and passed through the Sep-Pak C18 cartridge, which was then washed with $10 \mathrm{ml} 0 \cdot 1 \%$ trifluoroacetic acid (TFA). The cartridges were then eluted with $3 \mathrm{ml}$ $60 \%$ acetonitrile in $0.1 \%$ TFA and the elutes were dried under vacuum. The evaporates were reconstituted with the RIA buffer and measured in $\mathrm{T}_{3}$ and $\mathrm{T}_{4}$ kits as above. The recovery of radioiodinated $\mathrm{T}_{3}$ or $\mathrm{T}_{4}$ added to urine samples was $95 \pm 4$ and $97 \pm 8 \%$ (means \pm S.D., $n=6$ ) respectively. Graded volumes of the Sep-Pak eluates displaced the $T_{3}$ or $T_{4}$ tracers in parallel in RIAs. The immunoreactivity of the Sep-Pak evaporates moved in reverse-phase HPLC (Bondapak C18 column (Waters), polar buffer $0 \cdot 1 \%$ TFA and non-polar buffer 2-propanol, $1 \%$ gradient per minute from $10 \%$ propanol) at $12 \mathrm{~min}$ in the $\mathrm{T}_{3}$ RIA and at $13 \mathrm{~min}$ in the $\mathrm{T}_{4}$ RIA, corresponding to the elution positions of synthetic $T_{3}$ and $T_{4}$ respectively.

\section{Statistical analyses}

Seasonal variations in thyroid hormone and TSH levels were assessed by using ANOVA with repeated measures and Duncan's multiple range test for differences between the bimonthly means (BMDP, Los Angeles, CA, USA). Each hormone variable in an individual was proportioned to its annual mean before analyses in order to reduce the inter-individual variation.

The relationships between various thyroid hormone and TSH concentrations were assessed by using linear 
regression analyses and by Pearson's product moment correlation.

The relationships between the hormonal data (dependent variable) and climatic data (explanatory variable) were assessed by using multiple regression analyses. Since it was assumed that the climatic conditions that prevail at the time of blood sampling affect the hormonal levels, temperature and luminosity variables were integrated to the periods covering times $1-7,1-14,1-21,1-28,1-35$, $1-42,1-49,1-56$ and $1-63$ days before the time of blood sampling. Luminosity values (solar radiation) were transformed to logarithms (base 10) for regression analyses, since retinal cells discriminate luminosity more accurately on a logarithmic than an absolute scale.

\section{Results}

Environmental luminosity, temperature and serum thyroid hormones and TSH

Luminosity as expressed by averaged daily sums of solar radiation varied during the summer months between 10 and $20 \mathrm{MJ} / \mathrm{m}^{2}$ and decreased to almost 0 during December-February (Fig. 1, upper panel). The daily outdoor temperature was 5 to $20^{\circ}$ in May-August and 0 to $-40{ }^{\circ} \mathrm{C}$ in December-March (Fig. 1, second panel, mean of four daily recordings). The subjects spent $8 \cdot 0-9 \cdot 8 \mathrm{~h}$ outdoors in June-October and $5 \cdot 7-5 \cdot 8 \mathrm{~h}$ in DecemberFebruary $(P<0 \cdot 05$, Table 1$)$. There were no significant seasonal changes in body weight or caloric intake or in serum albumin levels (Table 1). Serum TSH levels were highest in December at $2 \cdot 1 \pm 0 \cdot 1 \mathrm{mU} / 1$ (means \pm s.E.), which was significantly higher $(P<0 \cdot 01)$ than during the other months (Fig. 1, third panel). Free $\mathrm{T}_{3}$ levels were highest in August at $4 \cdot 4 \pm 0 \cdot 2 \mathrm{pmol} / 1$, and lowest in February at $3 \cdot 9 \pm 0.1 \mathrm{pmol} / \mathrm{l}$, and this difference was statistically significant $(P<0 \cdot 05)$. Free $\mathrm{T}_{4}$ levels were between 14 and $15 \mathrm{pmol} / 1$ during the whole year $(P>0 \cdot 05)$. Total $\mathrm{T}_{3}$ and $\mathrm{T}_{4}$ levels varied between 1.8 and $1.9 \mathrm{nmol} / 1$ and 82 and $85 \mathrm{nmol} / 1$ during the 14 month observation period and no significant differences were seen between the months (Fig. 1, lower panels). Mean bimonthly $\mathrm{rT}_{3}$ levels varied between 0.4 and $0.7 \mathrm{nmol} / \mathrm{l}$, and no significant changes were seen either (data not shown).

The linear regression analyses between all the hormonal parameters demonstrated that $\mathrm{T}_{4}$ correlated significantly $(P<0 \cdot 01)$ with free $\mathrm{T}_{4}, \mathrm{~T}_{3}$ and free $\mathrm{T}_{3}$. Free $\mathrm{T}_{4}$ correlated significantly with $T_{3}$ and free $T_{3}$ and $T_{3}$ correlated with free $T_{3}$. The regression coefficient ranged between 0.44 and 0.77 (Table 2). Urinary $\mathrm{T}_{3}$ correlated significantly only with urinary $\mathrm{T}_{4}$.

Several regression models containing serum or urinary thyroid hormone concentrations or TSH as dependent and integrated temperature and/or solar radiation levels as explanatory variables were constructed. As to the circulating thyroid hormones, only serum free $T_{3}$ levels correlated significantly with climatic factors, i.e. with the temperature factors integrated for 1-7 days to $1-56$ days before the time when the blood sample for the measurements was taken (Table 3). The highest correlation occurred when the time factor was $1-56$ days $(r=0 \cdot 26$, Fig. 2). Interestingly, serum TSH correlated negatively $(r=-0.31)$ with all the solar radiation factors integrated between 1-7 and 1-56 days. The highest correlation was found when the radiation factor was 1-7 days $(r=-0 \cdot 31$, Table 3, Fig. 3). The temperature factors alone or combined with solar radiation did not result in a significant correlation between TSH and climatic factors. There were some sporadic correlations between TSH and temperature and urinary $\mathrm{T}_{3}$ and solar radiance.

\section{Urinary thyroid hormones}

Urinary $\mathrm{T}_{3}$ concentrations (Table 4) were the highest in February, $71 \pm 23 \mathrm{pmol} / \mathrm{l}$, and lowest in August, $43 \pm 17 \mathrm{pmol} / 1 \quad(P<0 \cdot 05)$. The $\mathrm{T}_{3}$ content of the firstvoided morning urine was $30 \pm 11 \mathrm{pmol}$ in February and $15 \pm 5 \mathrm{pmol}$ in August $(P<0 \cdot 01)$. There were no significant changes in urinary $T_{4}$ concentrations or in the $T_{4}$ contents of morning urines between the months. Urinary $\mathrm{T}_{3}$ levels correlated negatively with the temperature factor integrated from 1-14 days to 1-56 days, the highest correlation coefficient $(r=-0 \cdot 23$, Table 3 , Fig. 4) occurring when the factor was integrated for $1-28,1-35,1-42$, 1-49 or 1-56 days. Urinary $\mathrm{T}_{4}$ levels did not show any significant correlation between temperature or solar radiance.

\section{Discussion}

The results of the present study demonstrate that the subjects living in a circumpolar environment exhibit significant seasonal rhythmicities in serum TSH, free $\mathrm{T}_{3}$ and in urinary $\mathrm{T}_{3}$ but not in the levels of $\mathrm{rT}_{3}, \mathrm{~T}_{3}, \mathrm{~T}_{4}$, free $\mathrm{T}_{4}$ or urinary $\mathrm{T}_{4}$. We found that TSH was highest during the cold season (December) and free $\mathrm{T}_{3}$ in the summer (August). These findings are mostly in line with those obtained from hypothyroid patients in Japan and in healthy subjects during an Antarctic winter. Hypothyroid patients with constant $\mathrm{T}_{4}$ replacement tended to have low serum total $\mathrm{T}_{4}$ in winter, which points to the greater disposal of iodothyronines during cold seasons (Konno \& Morikawa 1982). After a 42 week residence in the Antarctic winter, serum $\mathrm{T}_{3}$ levels following oral administrations of $\mathrm{T}_{3}$ were found to be lower before it, indicating that the plasma clearance rate of $\mathrm{T}_{3}$ increased in the cold (Reed et al. 1990b). Thus, earlier findings and our present study suggest that during long-term cold exposure, such as in winter in circumpolar areas, the bodily disposal of thyroid hormones accelerates. The changes are small and are first 

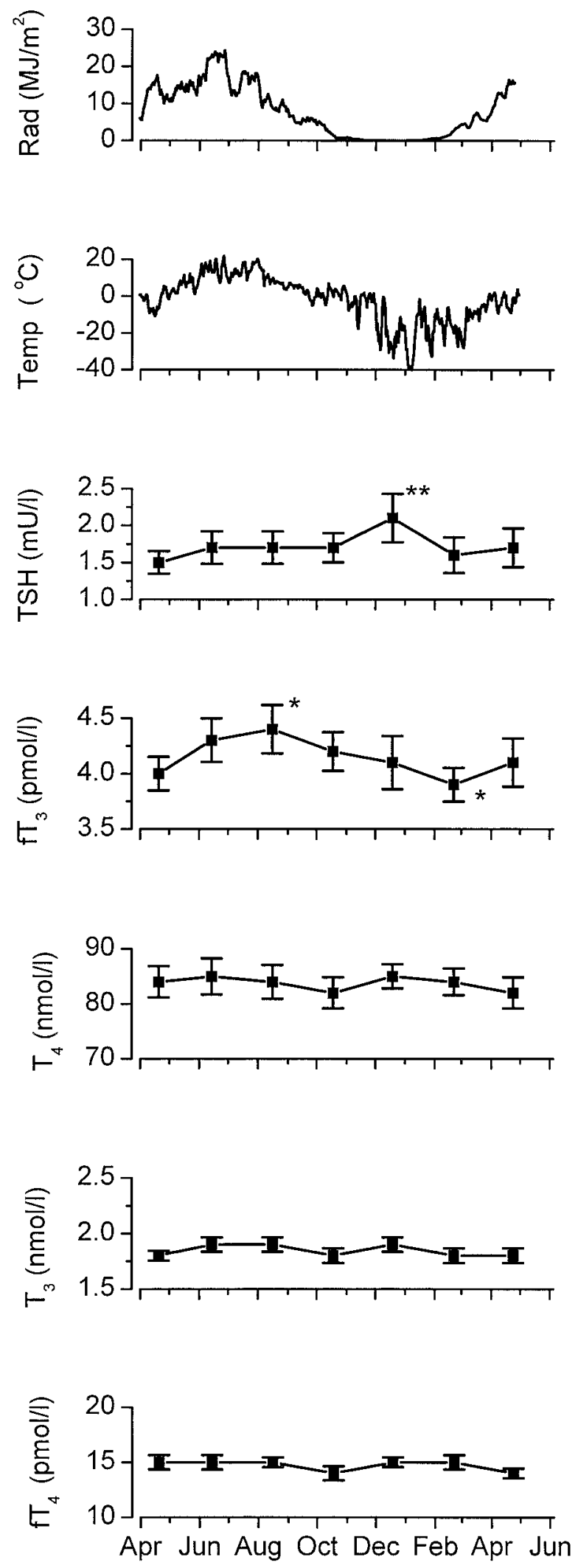

recognisable in serum free $\mathrm{T}_{3}$ levels (Reed et al. 1986, 1988 , this study) and later in total serum $\mathrm{T}_{3}$ or $\mathrm{T}_{4}$ levels (Vining et al. 1983, Reed et al. 1986, 1988, Harford et al. 1993). In our present study, cold exposure during winter was less intense than that experienced in the Antarctic winter. This is probably why we found serum total $T_{3}$ and $\mathrm{T}_{4}$ levels unchanged. One reason for the difficulty of finding decreases in serum $\mathrm{T}_{4}$ during cold exposure might be that the $T_{4}$ pool is much greater than the $T_{3}$ pool. An increased disposal of $\mathrm{T}_{3}$ as with $\mathrm{T}_{4}$ has been called the 'polar $\mathrm{T}_{3}$ syndrome' (Reed et al. 1990a,b).

In two European studies the relationship between ambient temperature and TSH or thyroid hormones has been studied. In older Italian subjects, elevated TSH levels were observed in winter, but the relationship between TSH and environmental temperature was not significant, indicating that temperature is not important in determining TSH levels (Simoni et al. 1990). In a Belgian study, serum TSH was significantly elevated in April, June and December and serum total $\mathrm{T}_{3}$ in December (Maes et al. 1997). The relationship between TSH and temperature was weak but significant between serum total $T_{3}$ and temperature. There is therefore evidence from the present and earlier studies that other possibilities besides temperature may affect the TSH circannual cycle and that these may interact with the temperature effect upon thyroid hormones.

In order to study the relationships between TSH and thyroid hormones and environmental factors more closely, we first compared serum and urinary thyroid hormones and TSH with each other. Serum $\mathrm{T}_{4}$ correlated significantly with other circulating thyroid hormone levels indicating a close $(r=0 \cdot 55-0 \cdot 77)$ relationship between these hormones in their production and metabolism. Urinary $T_{4}$ correlated significantly only with urinary $T_{3}$, most possibly for the same reason. Interestingly, there was no significant correlation between TSH and thyroid hormones or between circulating and urinary thyroid hormones. This may indicate that there are other mechanisms affecting the simple feedback loop between TSH and thyroid hormones and that the kidneys eliminate thyroid hormones in a manner independent of the circulating thyroid hormone levels.

Next, we compared TSH and thyroid hormones with outdoor temperatures and luminosity integrated backwards weekly for 56 days from the day the blood sample was taken. There was a highly significant negative correlation between TSH and solar radiation $(r=-0 \cdot 31)$ when the time factor was 1-7 days, indicating that approximately

Figure 1 Seasonal luminosity (radiance, Rad), temperature (Temp), serum TSH, and free and total thyroid hormones in 20 healthy male subjects from northern Finland $\left(67^{\circ}-68^{\circ} \mathrm{N}\right)$. For luminosity daily sums and temperature daily means are given, for hormones means \pm S.E. ${ }^{*} P<0.05$ between the lowest and highest value, ${ }^{*} P<0 \cdot 01$ between all the other points for serum TSH. 
Table 1 Seasonal variation of time spent outdoors, energy intake, body weight and serum albumin (means \pm S.E.) in 20 healthy males

\begin{tabular}{|c|c|c|c|c|c|c|c|}
\hline & Time of year & & & & & & \\
\hline & Apr & Jun & Aug & Oct & Dec & Feb & Apr \\
\hline Outdoor time $(\mathrm{h})$ & - & $8 \cdot 0 \pm 0 \cdot 7^{*}$ & $9 \cdot 8 \pm 0 \cdot 7^{* *}$ & $8 \cdot 3 \pm 0 \cdot 6^{*}$ & $5 \cdot 8 \pm 0 \cdot 6$ & $5 \cdot 7 \pm 0 \cdot 8$ & $6 \cdot 7 \pm 0 \cdot 8$ \\
\hline Energy intake (kcal) & $2627 \pm 220$ & $2770 \pm 240$ & $2717 \pm 180$ & $2674 \pm 200$ & $2780 \pm 180$ & $2722 \pm 180$ & $2735 \pm 140$ \\
\hline Body weight (kg) & $83 \cdot 2 \pm 2 \cdot 6$ & $83 \cdot 4 \pm 2 \cdot 8$ & $83 \cdot 4 \pm 2 \cdot 6$ & $82 \cdot 5 \pm 2 \cdot 6$ & $81 \cdot 4 \pm 2 \cdot 3$ & $82 \cdot 1 \pm 2 \cdot 3$ & $83 \cdot 5 \pm 2 \cdot 5$ \\
\hline Serum albumin $(\mathrm{g} / \mathrm{l})$ & $51 \pm 0 \cdot 7$ & $52 \pm 0 \cdot 8$ & $51 \pm 0 \cdot 8$ & $52 \pm 0 \cdot 6$ & $51 \pm 0 \cdot 4$ & $53 \pm 0 \cdot 5$ & $51 \pm 0 \cdot 6$ \\
\hline
\end{tabular}

${ }^{*} P<0 \cdot 05,{ }^{*} P<0 \cdot 01$ between any value when compared with the lowest value.

$10 \%$ of the variance in TSH is explained by luminosity. Previous regression analyses have shown that only $2 \cdot 9 \%$ of the variance in TSH was explained by air pressure but sunlight duration had no explanatory value (Maes et al.

Table 2 Pearson's correlation coefficients between serum TSH and serum and urinary thyroid hormone concentrations taken bimonthly for 14 months from 20 male subjects

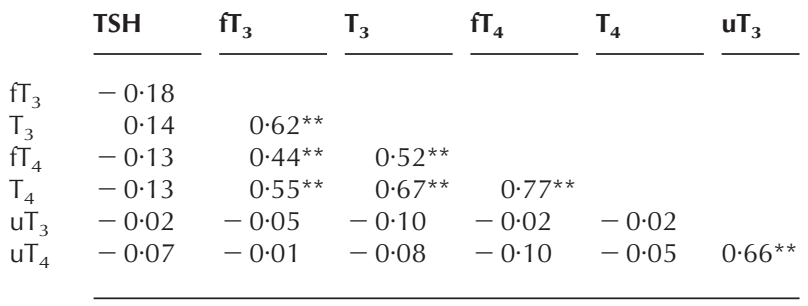

$\mathrm{f}=$ free, $\mathrm{u}=$ urinary. ${ }^{*} P<0 \cdot 01$.
1997). It is not known if the sunlight duration takes into account the actual radiation from the sun. The correlation between TSH and solar radiance diminished slowly with time, perhaps due to temporal autocorrelation of climatic factors. Since there was no significant correlation between $\mathrm{TSH}$ and temperature, we propose that the reduced luminosity in winter somehow stimulates the secretion of TSH. Another possibility is that the diurnal TSH rhythm is changed so that the night-time secretion period of TSH in winter extends into the morning, when our blood samples were taken. It has previously been observed that the diurnal rhythm of serum TSH can be shifted (phase delay) by a bright light stimulus (Allan \& Czeisler 1994), but we do not know the effects of decreasing daylength on the diurnal TSH secretory pattern.

When we correlated the circulating thyroid hormones with temperature or luminosity, only free $T_{3}$ was found to show a significant correlation with temperature. The

Table 3 Pearson's correlation coefficients in the linear regression models with hormone levels as dependent and climatic factors as explanatory variables

\begin{tabular}{|c|c|c|c|c|c|c|c|}
\hline Day factor & TSH & $\mathrm{fT}_{3}$ & $\mathbf{T}_{3}$ & $\mathrm{fT}_{4}$ & $\mathbf{T}_{4}$ & $\mathbf{u T}_{3}$ & $\mathrm{uT}_{4}$ \\
\hline \multicolumn{8}{|l|}{ Solar radiance } \\
\hline $1-7$ & $-0 \cdot 31^{* * *}$ & 0.05 & $-0 \cdot 05$ & $-0 \cdot 04$ & -0.07 & $-0 \cdot 11$ & $-0 \cdot 11$ \\
\hline $1-14$ & $-0 \cdot 31^{* * *}$ & 0.06 & $-0 \cdot 05$ & -0.05 & -0.07 & $-0 \cdot 11$ & $-0 \cdot 11$ \\
\hline $1-21$ & $-0 \cdot 30^{* * *}$ & $0 \cdot 08$ & $-0 \cdot 04$ & -0.06 & -0.08 & $-0 \cdot 13$ & $-0 \cdot 12$ \\
\hline $1-28$ & $-0 \cdot 30^{* * *}$ & 0.09 & -0.03 & -0.07 & -0.08 & $-0 \cdot 14$ & $-0 \cdot 12$ \\
\hline $1-35$ & $-0 \cdot 28^{\star *}$ & $0 \cdot 11$ & $-0 \cdot 02$ & -0.07 & -0.08 & $-0 \cdot 15$ & $-0 \cdot 13$ \\
\hline $1-42$ & $-0 \cdot 27^{* *}$ & $0 \cdot 12$ & $-0 \cdot 01$ & -0.08 & -0.08 & $-0 \cdot 16$ & $-0 \cdot 13$ \\
\hline $1-49$ & $-0 \cdot 25^{\star *}$ & $0 \cdot 14$ & $0 \cdot 00$ & -0.09 & -0.08 & $-0 \cdot 17$ & -0.13 \\
\hline $1-56$ & $-0 \cdot 22^{*}$ & $0 \cdot 15$ & $0 \cdot 02$ & $-0 \cdot 10$ & -0.07 & $-0 \cdot 18^{\star}$ & $-0 \cdot 12$ \\
\hline \multicolumn{8}{|l|}{ Temperature } \\
\hline $1-7$ & $-0 \cdot 19^{*}$ & $0 \cdot 19^{*}$ & $0 \cdot 02$ & $-0 \cdot 04$ & -0.03 & $-0 \cdot 14$ & $-0 \cdot 14$ \\
\hline $1-14$ & $-0 \cdot 15$ & $0 \cdot 21^{*}$ & $0 \cdot 05$ & -0.05 & -0.02 & $-0 \cdot 18^{*}$ & $-0 \cdot 15$ \\
\hline $1-21$ & $-0 \cdot 16$ & $0 \cdot 22^{*}$ & $0 \cdot 05$ & -0.05 & -0.01 & $-0 \cdot 21^{*}$ & $-0 \cdot 16$ \\
\hline $1-28$ & $-0 \cdot 12$ & $0 \cdot 23^{*}$ & $0 \cdot 08$ & -0.06 & $0 \cdot 00$ & $-0 \cdot 23^{*}$ & $-0 \cdot 15$ \\
\hline $1-35$ & $-0 \cdot 10$ & $0 \cdot 24^{*}$ & 0.09 & -0.06 & -0.01 & $-0 \cdot 23^{*}$ & $-0 \cdot 15$ \\
\hline $1-42$ & $-0 \cdot 10$ & $0 \cdot 24^{*}$ & 0.09 & -0.05 & -0.01 & $-0 \cdot 23^{*}$ & -0.15 \\
\hline $1-49$ & -0.07 & $0 \cdot 24^{*}$ & $0 \cdot 10$ & -0.06 & -0.01 & $-0 \cdot 23^{*}$ & $-0 \cdot 14$ \\
\hline $1-56$ & -0.07 & $0 \cdot 26^{*}$ & $0 \cdot 12$ & -0.06 & -0.02 & $-0 \cdot 23^{*}$ & $-0 \cdot 14$ \\
\hline
\end{tabular}

Day factor is the period in days that preceded the day when the blood samples for hormonal measurements were taken and that was integrated for solar radiance or temperature for the linear regression models.

${ }^{*} P<0 \cdot 05,{ }^{* *} P<0 \cdot 01,{ }^{* * *} P<0 \cdot 001$.

$\mathrm{f}=$ free, $\mathrm{u}=$ urinary. 


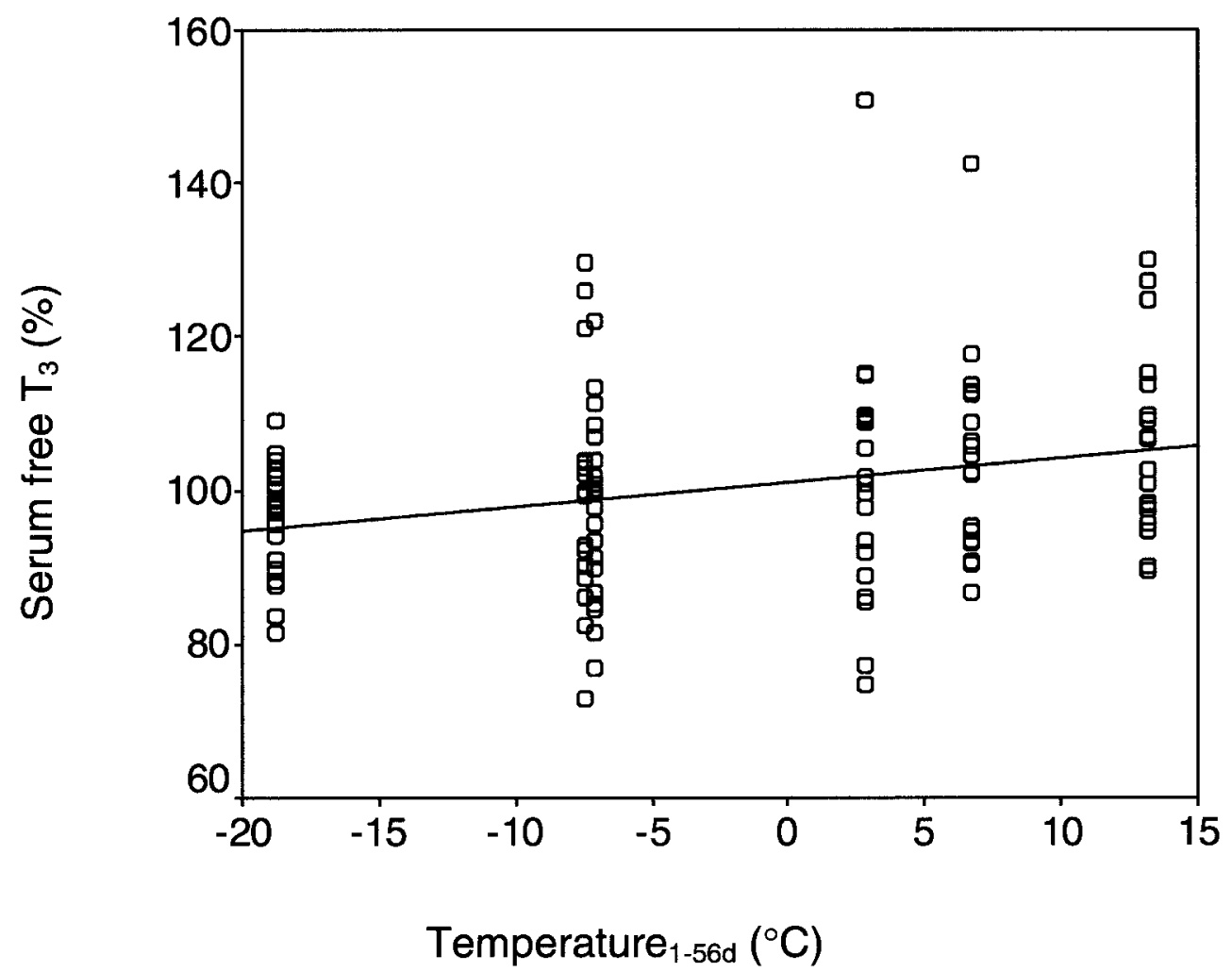

Figure 2 Bimonthly mean serum free $\mathrm{T}_{3}$ (per cent of the annual mean) as a function of ambient temperature integrated back for 56 days from the day of blood sampling for the $T_{3}$ measurements in 20 male subjects. There is a significant positive correlation between serum free $T_{3}$ and ambient temperature $(r=0 \cdot 26, P<0 \cdot 05)$.

correlation was best $(r=0 \cdot 26)$, when the temperature factor was 1-56 days, explaining approximately $7 \%$ of the variance in free $\mathrm{T}_{3}$. In an earlier study an increase in serum total $\mathrm{T}_{3}$ during winter, and therefore a highly significant negative correlation between total $\mathrm{T}_{3}$ and temperature, had been reported (Maes et al. 1997). The negative correlation is difficult to understand, because in the majority of the studies dealing with seasonal changes in the secretion of thyroid hormones there are rather decreases in the levels of free or total $\mathrm{T}_{3}$ during winter (Vining et al. 1983, Reed et al. 1986, 1990a,b, Harford et al. 1993, this study). We interpret our results so that at the end of winter the tissue uptake/metabolic degradation of $\mathrm{T}_{3}$ gradually exceeds its production rate and leads to decreased levels of free $\mathrm{T}_{3}$. The increased tissue uptake may also explain the increased urinary secretion of $T_{3}$ which we observed in late winter.

In the Belgian subjects an inverse relationship between serum total $\mathrm{T}_{3}$ and ambient temperature of the preceding week was observed that was partly determined by TSH (Maes et al. 1997). These findings are difficult to reconcile, since we observed neither seasonal changes in serum total $\mathrm{T}_{3}$ nor any relationships between TSH and thyroid hormones. An experimental study in which healthy sub- jects were repeatedly exposed to cold air and in which free $\mathrm{T}_{3}$ was found to be decreased with no changes in other thyroid hormone or TSH levels (Hesslink et al. 1992) supports our present observation. We point out that other seasonal changes in outdoor activities, luminosity, caloric intake, body weight or serum albumin do not explain our findings, since we did not find any significant changes in these parameters during our study.

There are some indirect findings supporting increased TSH secretion during the cold season. Ultrasonically measured thyroid volumes were found to be $23 \%$ greater in winter than in summer, even though serum TSH and thyroid hormones were not significantly changed in healthy subjects from Denmark (Hegedus et al. 1987). The same authors then concluded that the seasonal variation in thyroid size should be taken into account, for example in goitre treatment.

Measurements of urinary thyroid hormone concentrations have been used for the evaluation of thyroid activity. Previous methods utilised untreated urine samples or simple extractions (Rastogi \& Sawhney 1976). In our experience untreated or extracted urine samples did not give reliable results and we adopted a reverse-phase Sep-Pak cartridge method for the purification of urine 


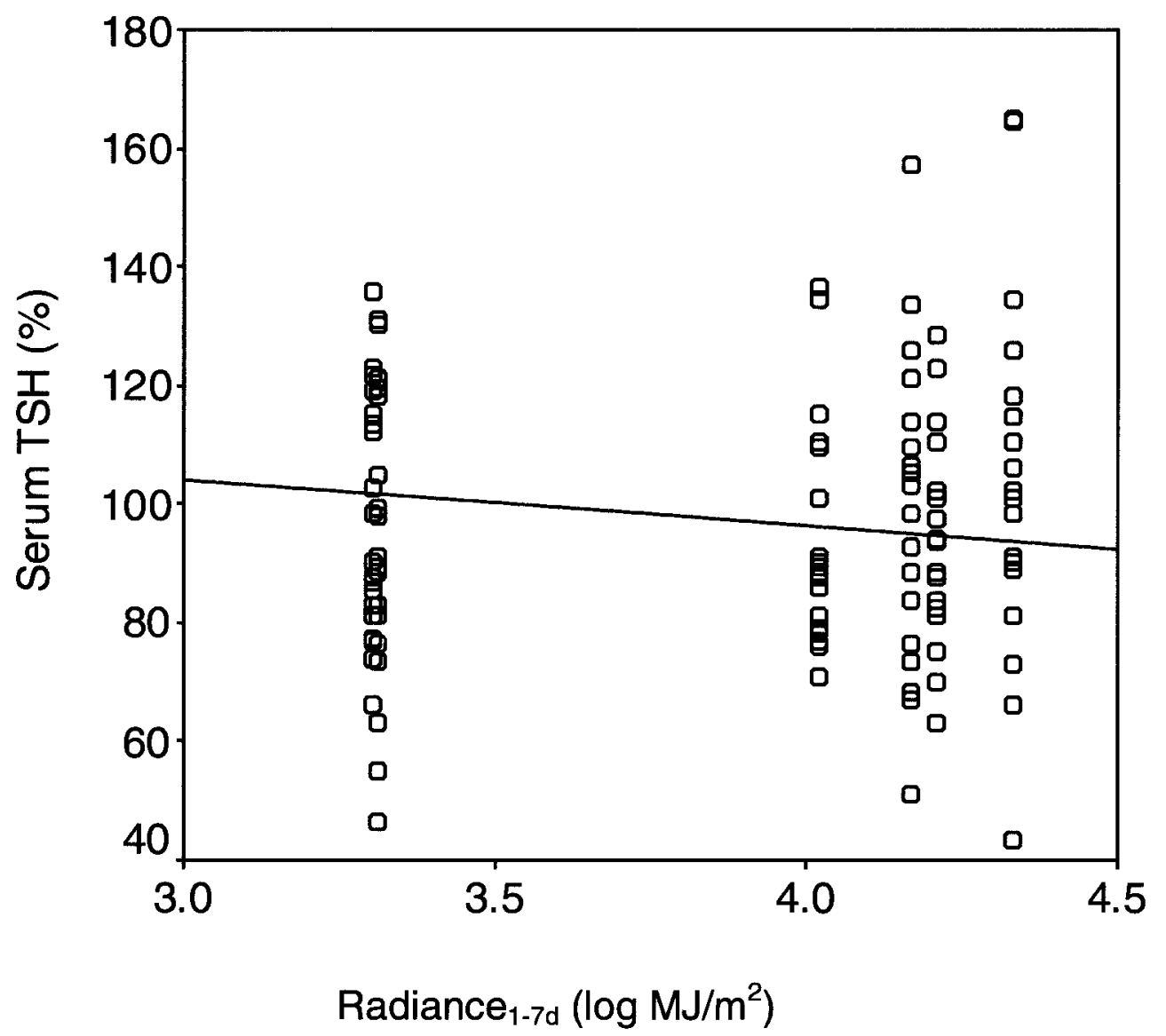

Figure 3 Bimonthly mean TSH (per cent of the annual mean) as a function of luminosity (solar radiance) integrated back for 7 days from the day of blood sampling for TSH measurements in 20 male subjects. There is a significant inverse correlation between the parameters $(r=-0.31, P<0.001)$.

samples for thyroid hormone RIAs. The recovery of the method was good, and the $T_{3}$ and $T_{4}$ immunoreactivities of the Sep-Pak eluates moved in HPLC as synthetic $\mathrm{T}_{3}$ and $\mathrm{T}_{4}$ respectively. By using this method we obtained urine $\mathrm{T}_{3}$ concentrations of $40-70 \mathrm{pmol} / 1$ and $350-$ $470 \mathrm{pmol} / 1$ for $\mathrm{T}_{4}$. These values were approximately one-tenth of those presented earlier (Rastogi \& Sawhney 1976). Taking the improved purification method into account, our urinary $T_{3}$ and $T_{4}$ values most probably present 'true' urinary free thyroid hormone levels. Serum free $T_{3}$ levels and urinary $T_{3}$ levels showed opposite trends in our study. Moreover, urinary $\mathrm{T}_{3}$ correlated significantly with temperature $(r=-0 \cdot 23$, when the time factor was more than 4 weeks) indicating that approximately $5 \%$ of the variance in the urinary $\mathrm{T}_{3}$ is explained by temperature. These findings may be related to an increased uptake of $T_{3}$ in the kidneys as we discussed before, and also to the increased formation of $T_{3}$ from $T_{4}$ in the kidneys, as we

Table 4 Seasonal variation of urinary $\mathrm{T}_{3}$ and $\mathrm{T}_{4}$ in 20 healthy men (means \pm S.D.)

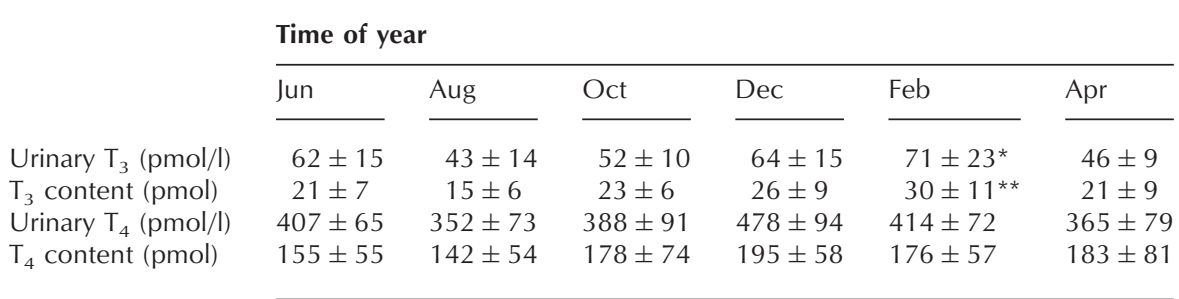

${ }^{*} P>0 \cdot 05,{ }^{*} P<0 \cdot 01$ between the highest and lowest value. 


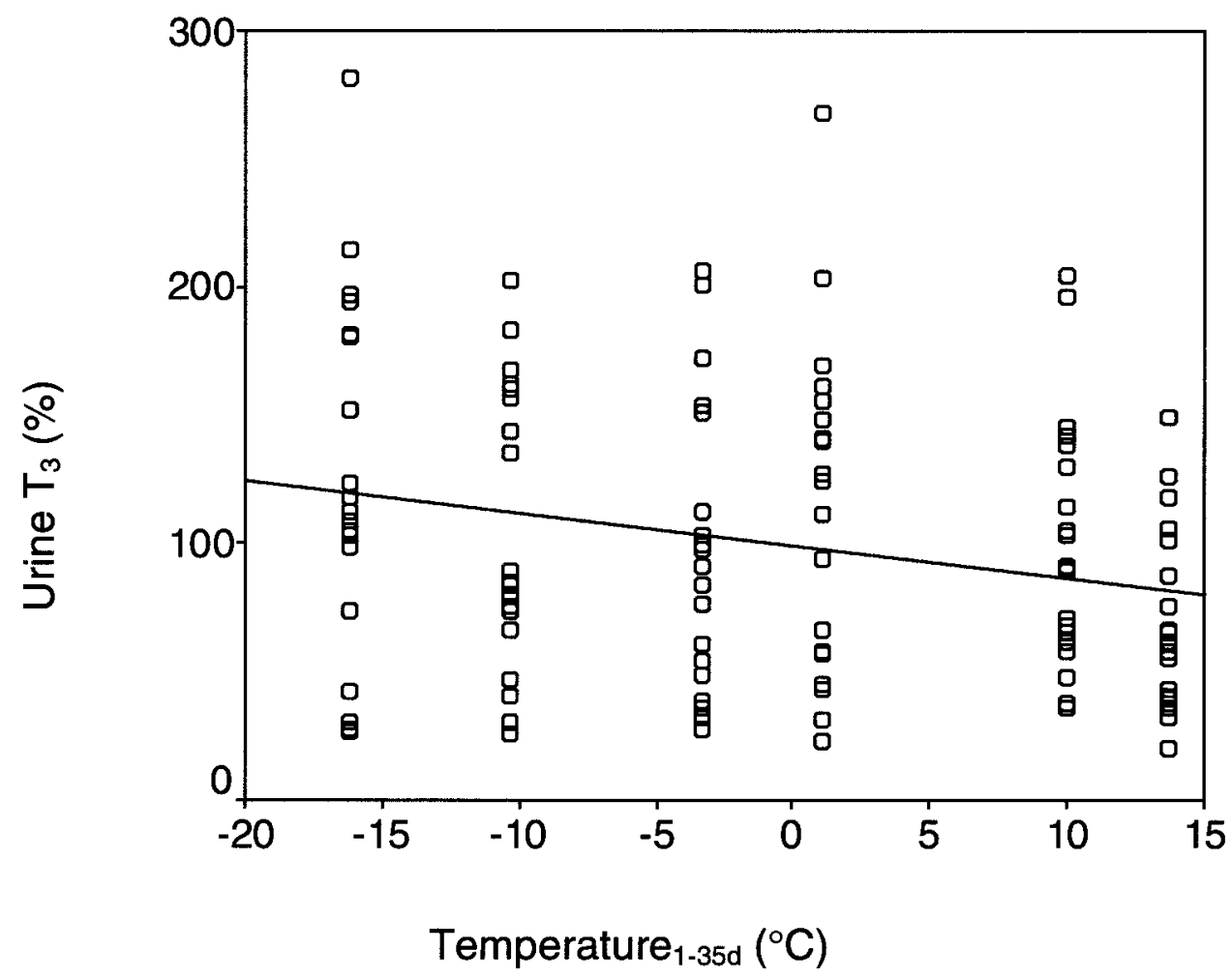

Figure 4 Bimonthly mean urinary $T_{3}$ (per cent of the annual mean) as function of the ambient temperature integrated back for 35 days from the day of blood sampling in 20 male subjects. There is a significant inverse correlation between the parameters $(r=-0 \cdot 23, P<0 \cdot 05)$.

found a significant correlation between urinary $\mathrm{T}_{3}$ and $\mathrm{T}_{4}$. In healthy human males the daily production of $\mathrm{T}_{3}$ is reported to be $78-113 \mathrm{nmol} / \mathrm{m}^{2}$ (Reed et al. 1990b) and the urinary content of free $T_{3}$, about $0.1 \mathrm{nmol}$, is only a small fraction of it. In spite of this, the urinary excretion of free $\mathrm{T}_{3}$ represents a novel and non-invasive indicator for studies in thyroid physiology.

The results of our study suggest that decreasing ambient temperature in winter gradually increases the disposal of thyroid hormones, seen in falling serum free $\mathrm{T}_{3}$ levels, which reach the minimum at the end of winter. Serum TSH levels increase also in December and may be associated with reduced ambient luminosity. According to our present results the association between serum TSH with free $T_{3}$ is not clear, since low free $T_{3}$ and high TSH levels did not occur at the same time. In this climate the cold exposure may not have been intense enough to cause changes in serum $\mathrm{T}_{3}$ as well as in free or total $\mathrm{T}_{4}$. The urinary free $T_{3}$ showed opposite seasonal curves to serum free $\mathrm{T}_{3}$ levels and this may indicate increased disposal of $\mathrm{T}_{3}$ during cold exposures.

Increased metabolic clearance of thyroid hormones during the cold season has several clinical consequences. As presented above, the substitution doses of thyroid hormones could be increased in winter (Konno \& Morikawa 1982). This may be advantageous also in goitre patients (Hegedus et al. 1987). Decreased thyroid hormones tend to increase blood lipid levels (Harford et al. 1993) and minimal thyroid dysfunction is often associated with increased levels of low density lipoprotein cholesterol (Staub 1998), established risk factors for cardiovascular diseases. More studies are, however, required to screen populations living in circumpolar areas to determine who could benefit from a substitution with thyroid hormones in winter.

\section{References}

Allan JS \& Czeisler CA 1994 Persistence of the circadian thyrotropin rhythm under constant conditions and after light-induced shifts of circadian phase. Journal of Clinical Endocrinology and Metabolism 79 508-512.

Harford RR, Reed HL, Torris MT, Sapier IE, Warden R \& D’Alesandro MM 1993 Relationship between changes in serum thyrotropin and total and lipoprotein cholesterol with prolonged Antarctic residence. Metabolism 42 1159-1163.

Harrop JS, Ashwell K \& Hopton MR 1985 Circannual and within-individual variation of thyroid function tests in normal subjects. Annals of Clinical Biochemistry 22 371-375. 
Hegedus L, Rasmussen N \& Knudsen N 1987 Seasonal variations in thyroid size in healthy males. Hormone and Metabolic Research 19 391-392.

Hesslink RL, D'Alesandro MM, Armstrong DW \& Reed HL 1992 Human cold air habituation is independent of thyroxine and thyrotropin. Journal of Applied Physiology: Respiratory, Environmental and Exercise Physiology 72 2134-2139.

Konno N 1978 Comparison between the thyrotropin response to thyrotropin-releasing hormone in summer and that in winter in normal subjects. Endocrinologia Japonica 25 635-639.

Konno N \& Morikawa K 1982 Seasonal variation of serum thyrotropin concentration and thyrotropin response to thyrotropin-releasing hormone in patients with primary hypothyroidism on constant replacement dosage of thyroxine. Journal of Clinical Endocrinology and Metabolism 54 1118-1124.

Laitinen J, Näyhä S, Sikkilä K \& Hassi J 1996 Diet and cardiovascular risk factors among Lapp and Finnish reindeer herders. Nutritional Research 16 1083-1093.

Maes M, Mommen D, Hendrickx D, Peeters D, D'Hondt P, Ranjan R, De Meyer R \& Scharpé S 1997 Components of biological variation, including seasonality, in blood concentrations of TSH, $\mathrm{TT}_{3}, \mathrm{FT}_{4}, \mathrm{PRL}$, cortisol and testosterone in healthy volunteers. Clinical Endocrinology 46 587-598.

Nagata H, Izumiyama T, Kamata K, Konno S, Yukimura Y, Tawata M, Aizawa T \& Tamada T 1976 An increase of plasma triiodothyronine concentration in man in a cold environment. Journal of Clinical Endocrinology and Metabolism 43 1153-1157.

Pasquali R, Baraldi G, Casimirri F, Mattioli L, Capleii M, Melchionda N, Capani F \& Labò G 1984 Seasonal variations of total and free thyroid hormones in healthy men: a chronobiological study. Acta Endocrinologica 107 42-48.

Rastogi GK \& Sawhney RC 1976 Significance of urinary excretion of triiodothyronine $\left(\mathrm{T}_{3}\right)$ and thyroxine $\left(\mathrm{T}_{4}\right)$. Indian Journal of Medical Research 64 1639-1648.
Reed HL, Burman KD, Shakir KMM \& O'Brian JT 1986 Alterations in the hypothalamic pituitary thyroid axis after prolonged residence in Antarctica. Clinical Endocrinology 25 55-65.

Reed HL, Ferreiro JA, Shakir KMM, Burman KD \& O'Brian JT 1988 Pituitary and peripheral hormone responses to $T_{3}$ administration during Antarctic residence. American Journal of Physiology 254 E733-E739.

Reed HL, Brice D, Shakir KMM, Burman KD,D'Alesandro MM \& O'Brian JT 1990a Decreased free fraction of thyroid hormones after prolonged Antarctic residence. Journal of Applied Physiology 69 1467-1472.

Reed HL, Silverman ED, Shakir KMM, Dons R, Burman KD \& O'Brian JT 1990b Changes in serum triiodothyronine $\left(\mathrm{T}_{3}\right)$ kinetics after prolonged Antarctic residence: the polar $\mathrm{T}_{3}$ syndrome. Journal of Clinical Endocrinology and Metabolism 70 965-974.

Simoni M, Velardo A, Montanini V, Faustini Fustini M, Seghedoni S \& Marrama P 1990 Circannual rhythm of plasma thyrotropin in middle-aged and old euthyroid subjects. Hormone Research $\mathbf{3 3}$ 184-189.

Smals AGH, Ross HA \& Kloppenborg PWC 1977 Seasonal variation in serum $\mathrm{T}_{3}$ and $\mathrm{T}_{4}$ levels in man. Journal of Clinical Endocrinology and Metabolism 44 998-1001.

Staub JJ 1998 Minimal thyroid failure: effects on lipid metabolism and peripheral target tissues. European Journal of Endocrinology $\mathbf{1 3 8}$ 137-138.

Vining R, McGinley R, Holliday L, Williams L \& Compton P 1983 Seasonal variation in hormonal concentrations in Australian Antarctic personnel. Endocrine Society of Australia Proceedings 2679 (Abstract).

Received 7 November 2000 Accepted 8 December 2000 